\title{
PUSH UP DEVELOPMENT TEST INSTRUMENTS BASED ON SENSOR TECHNOLOGY
}

\author{
M. Ageng Aidil Ramdhon' ${ }^{1}$ Hartati $^{2}$, Sri Sumarni ${ }^{3}$ \\ ${ }^{1,2,3}$ Pendidikan Olahraga, Universitas Sriwijaya, Palembang, Indonesia
}

\begin{tabular}{l}
\hline Info Artikel \\
\hline Article History: \\
Received July 2020 \\
Revised July 2020 \\
Accepted August 2020 \\
Available online September 2020 \\
\\
Keywords: \\
Instruments, Push Up, Sensor \\
Teknology \\
\hline
\end{tabular}

\begin{abstract}
This study aims to develop a sensor technology-based push up test instrument for Sriwijaya State Sports School students. The research method used is research and development (research and development). Development research subjects were divided into two groups. Small-scale group trials consist of 10 students and large-scale group trials consist of 21 students. The results showed that the sensor technology-based push-up test instrument had a $94 \%$ validity test and sports measurement expert level and an IT expert validity of $75 \%$ so that the tool could be said to be feasible. The level of reliability in trials of small groups of men amounted to 0.994 and small groups of women amounted to 0.988 with the High category. Whereas the large group of male trials was 0.998 and the large group of women was 0.946 with the High category so it was said that the level of tool reliability was carried out in the large group and small group trials having the High reliability category. The implication of this research is that the development of sensor technology-based push up test instruments can be used as a valid, effective, and practical push up measurement tool.
\end{abstract}

Corresponding address: Jl. Masjid Al Gazali, Bukit Lama, Kec. Ilir Bar. I,
Kota Palembang, Sumatera Selatan
E-mail
: hartati @ fkip.unsri.ac.id

ISSN 2685-6514 (online)

ISSN 2477-331X (print)

DOI : $10.33369 / j k . v 4 i 2.12023$ 


\section{INTRODUCTION}

Physical condition is one of components needed attention from sports coaches as a basic in supporting the improvement of athlete's ability. Syafruddin (2011: 76) states that there are 4 elements that affect the sports achievement, they are physical, technical, tactical, and mental conditions. The physical condition test reflects the each athlete ability so that it can be seen from the athlete's initial ability (Bafirman, 2010: 7).

Sports test and measurement aids are widely used by coaches in facilitating the process of monitoring the development of athletes 'physical components, making notes and being used as a basis for diagnosing athletes' weaknesses, and being able to determine training programs that are applied to certain sports. Currently, sports measurement test aid equipment still relies on foreign products, so it requires a large budget expenditure. Backs room (2013: 215) argues that if a country only acts as a consumer of sports technology, it will be very unlikely to make achievements at the international level in various sports. Limited research and funds have resulted in the provision of sports technology aids not running according to needs (James and Petrone, 2016: 1).

Arm muscle strength is one of physical conditions components that don't have measurement tools. The measurement of arm muscle strength still uses push up conventional instruments test. Irawan (2018: 32) explains that the weakness of test push up the conventional is subjective supervision. Another weakness that exists in push-ups conventional is in practicality tests terms that require equipment such as stationery, test forms, and stopwatches that are operated manually so that they are prone to errors in their supervision (Rosadi, 2018: 35). Errors in obtaining measurement data cause the athlete's condition monitoring program to be less than optimal (Aprilio and Yasrudin, 2016: 9).

The observations results by Sriwijaya State Sports High School (SONS) through the push up conventional tests measurement on 16 students using two supervisors showed that there was a difference in the average result acquisition between the first supervisor and the second supervisor. The average result of the first supervisor was 36.37 and the second supervisor was 38.56 , so there was a difference between the first and second supervisors of 2.19. Based on these results indicate that the tests carried out didn't meet the objective requirements. Winarno (2004: 47) argues that a test is said to be objective if the measurements made by several people get relatively the same results.

Wiarto (in Rahmat, 2017: 140) argues that technology has a big influence in sports sphere. Technological advances are used by developed countries in assisting observation, gathering information, and processing data in a short time (Kos et.al, 2018: 490). The solution in overcoming the problem of the weaknesses in test calculations push up conventional requires a detector motion push up automatic tool that can increase effectiveness and efficiency, and obtain certain desired values from the implementation of pushup activities itself (Kusmindari, 2016: 2).

Rosadi (2018: 36) states that measurement technology test on push up used ultrasonic sensor based can produce data in a high validity level compared to manual testing. The sensor ultrasonic consists of two units, namely a transmitter and receiver unit, where the ultrasonic 
sensor generally emits ultrasonic waves towards a target and reflects the waves back towards the sensor (Arsada, 2017: 135). The test tool push up using sensor technology can make it easier for trainers to obtain valid, effective, and practical measurement data.

Based on the description above, the researcher is interested in "Test Instruments Push Up Development of Sensor Technology Based for Sriwijaya State Sports School Students."

\section{METHOD}

This research uses research and development methods. Research and development (R\&D) method is a research method used to produce certain products and effectiveness test of these products. This research aims to develop instrument test of push up sensor technology-based. The stages or research and development steps in this study are: 1) needs analysis, 2) observation, 3) product design, 4) design validation, 5) design improvement, 6) small-scale group trials, 7) product revision , 8) large-scale group trials, 9) product revisions, and 10) final products (Sugiyono, 2017: 408).

The subjects in this development research were divided into two groups. Small-scale group trials were conducted on 10 Sriwijaya State Sports High School students. Which consists of 7 swimming students and 3 karate students. Largescale group trials were carried out on 21 Sriwijaya State Sports High School students consisting of 16 volleyball students and 5 gymnastic students. The technique of selecting research subjects used sampling technique. This research used sampling technique with certain considerations, in this case, researcher chooses a sport that is dominant in the use of arm muscle strength.
Expert validation is done by asking for expert assessments by filling out a questionnaire provided in certain fields such as sports test and measurement experts and IT experts. Reliability is obtained by calculating the correlational value of small-scale group trials and largescale group trials using the test and retest method.

\section{RESULTS AND DISCUSSION}

\section{Results}

The research on a test push up sensor technology-based development was conducted at Sriwijaya State Sports School. The research subjects consisted of 31 students in Sriwijaya State Sports High School. The research implementation was divided into two stages, namely product testing in small-scale groups consisting of 10 students and product testing in largescale groups consisting of 21 students. The initial data monitoring was carried out through measurement process for push-up conventional SONS students using two test supervisors. The observations results showed a significant difference in the average yield of first supervisors and second supervisors. The average result for the first supervisor was 36.37 and second supervisor scored 38.56 , so there was a difference in the average result of 2.19 . Based on these results, it shows that the tests carried out didn't meet the objectivity requirements.

The product designed used is a digital measurement tool push up that aims to correct weaknesses in the implementation tests push up conventional implementation. The components needed to make instrument test for push up a sensor-based include ultrasonic sensors, mattresses, cables, laptops, buzzers, and microcontrollers. 
Product validation is done by asking for assessment of two experts they are sports test and measurement experts and IT experts. Validation is done by displaying the workings test instrument product push up of sensor technologybased, accompanied by a validation sheet in the form of a questionnaire using a scale. The expert validation results can be seen in the table below:

Table 1. Expert Validation

\begin{tabular}{|c|c|c|c|}
\hline Validator & $\begin{array}{l}\text { Valu } \\
\text { e }\end{array}$ & $\begin{array}{c}\text { Percentag } \\
\mathrm{e}\end{array}$ & $\begin{array}{c}\text { Categor } \\
\mathrm{y}\end{array}$ \\
\hline \multirow{2}{*}{$\begin{array}{l}\text { Experts for } \\
\text { sports tests } \\
\text { and } \\
\text { measuremen } \\
\text { ts }\end{array}$} & & & \\
\hline & 94 & $94 \%$ & Eligible \\
\hline IT experts & 75 & $75 \%$ & Eligible \\
\hline
\end{tabular}

Based on table 1 above, the validation results obtained a percentage level of $94 \%$ at experts in sports tests and measurements and a $75 \%$ percentage rate on IT experts. Based on the results of the validation, it can be said that the push up instrument test based on sensor technology has a decent category.

Product revisions are made after expert advice is obtained in order to perfect the tools being made. The revised component is to improve the of the support column section so that it calibrated according to athlete's arm height. Furthermore, there are improvements in the application program to change the reset system to time counter be automatic.The revised product was continued by testing 31 students which were divided into small group trials and large group trials. The results of these tests can be seen in the table below:
Table 2.Correlation Coefficient Category Reliability Small Group

\begin{tabular}{cccc}
\hline N & Gender & Correlation & $\begin{array}{c}\text { Reliability } \\
\text { Coefficient }\end{array}$ \\
\hline 4 & Boys & 0.994 & High \\
\hline 6 & Girls & 0.988 & High \\
\hline
\end{tabular}

Based on reliability trials in a small male group consisting of 4 students, the reliability correlation coefficient is obtained 0.994 and a small group of girls consisting of 6 students obtained a reliability correlation coefficient of 0.988 , so it can be said that the results of smallscale trials have a reliability correlation coefficient with a high category.

Table 3.Category Correlation Coefficient Reliability Male Group

\begin{tabular}{cccc}
\hline $\mathrm{N}$ & Gender & Correlation & $\begin{array}{c}\text { Reliability } \\
\text { Coefficient }\end{array}$ \\
\hline 12 & Boys & 0.998 & High \\
\hline 9 & Girls & 0.946 & High \\
\hline
\end{tabular}

Based on the reliability test the large male group consisting of 12 students obtained a reliability correlation coefficient of 0.998 and a small girl group consisting of 9 students obtained The reliability correlation coefficient is 0.946 , it can be said that the large-scale trials results have a high reliability correlation coefficient.

The product produced in this study is a measurement tool push up using technology ultrasonic sensor that is integrated into a microcontroller so that the results of the push up movement can be input and stored in application program push up counter on the laptop. 


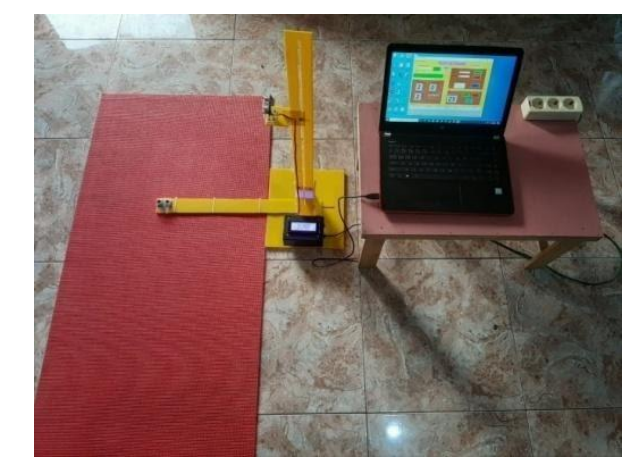

Picture. 1. The test instrument push-up technology based sensor

The measures of test instrument implementation push up based sensor technology are as follows:

1. Activate the tool circuit by connecting the sensor device to a laptop to get power.

2. Open the program push up counter on the laptop.

3. After opening the application the user clicks menu connect and to make sure the sensor circuit is detected by the laptop, check by selecting the port.

4. Third, enter the name of the tester in the program application, then save it. Then the tester takes a position on the mat that has been provided to prepare to do pushups.

5. Click start to start push up test.

6. The test will last for 1 minute, if the time is up, the program will not count the movements performed. The tester result data will be saved automatically.

\section{DISCUSSION}

This research is attest instrument push up sensor technology-based development. Tool design's done to correct the weaknesses in measurements push up conventional push up measurement. Irawan (2018: 32) explains that the weakness of push up test is the conventional subjective supervision. Errors in obtaining measurement data cause the athlete's condition monitoring program to be less than optimal (Aprilio and Yasrudin, 2016: 9). Suryabrata (2008: $31)$ states that a data collection tool or a test instrument can affect the quality of the data obtained. Therefore, it is necessary to have a tool detector motion push up automatic that can increase effectiveness and efficiency, and obtain certain desired values from the implementation of activities push-up itself (Kusmindari, 2016: 2).

Sensor technology is often used for the detection and control of an object's movement (Akagi et.al, 2016: 1). The development of push up test instruments sensor technology-based can minimize errors made in monitoring movement's push-up and the form of technology use in sports can provide the attractiveness of the tester to be measured (Nillson, 2016: 4). According to Park et.al, (2010: 342) that through the development of this tool it can provide results with a high level of accuracy and especially differences in the use of tools are able to shorten the process of processing test data, because the test result data obtained is connected and stored in the program application in laptop.

It works about the sensor technologybased by utilizing two sensors ultrasonic connected to an Arduino microcontroller to monitor the tester in doing push up movements. The information captured on both sensors will be sent to the microcontroller and worked so that it can display the data from the push up results.

Muzakir (2016: 94) suggests that a microcontroller is a chip that has a function as a regulator of a system. Furthermore, the buzzer component will sound if a motion is detected push up by the tester and vice versa the buzzer will not sound if the tester movement is not detected on the sensor. The test data 
results that have been carried out will be inputted into the application program push up counter and stored in the excel format.

\section{CONCLUSION}

Based on the data processing and analysis results that has been done, it can be concluded that test instrument push up the sensor technology-based can be used as tool for calculating tests push up a valid, effective and practical. This tool is called a push-up counter which has advantages, especially in its effectiveness, objective measurement process, and helps the managing practicality the measurements results on push up.

\section{SUGGESTION}

Some advice that can be given in this research are:

1. Sports coaches are expected to continue to develop research and innovation in the use of technology in supporting the athlete development process.

1. For future researchers, it is hoped that they will be able to improve the limitations of the development of the tools made. Therefore it is necessary to use a digital camera in order to get measurement results push up optimal.

\section{REFERENCES}

Akagi, T., Dohta, S., Morimoto, T., Matsui, Y., \& Shimooka, S. (2016). Development Of Compact Flexible Displacement Sensors Using Ultrasonic Sensor For Wearable Actuators.In Matec Web Of Conferences (Vol. 51, P. 02002). Edp Sciences.

Aprilo, I., \& Yasriuddin, Y. (2016). Studi Awal Pengembangan Instrument Tes Push Up Berbasis It. Jurnal Ilara, 7(2), 1-107.
Arsada, B. 2017.Aplikasi Sensor Ultrasonik Untuk Deteksi Posisi Jarak Pada Ruang Menggunakan Arduino Uno.Jurnal Teknik Elektro, 6(2), 137135.

Backstrom, M., Tinnsten, M., Koptyug, A., Rannar, L. E., Carlsson, P., Danvind, J., \& Wiklund, H. (2013). Sports Technology Education At Mid Sweden University. Procedia Engineering, 60, 214-219.

Bafirman. (2010). Pembentukan Kondisi Fisik. Padang: Fakultas Ilmu Keolahragaan Universitas Negeri Padang. Wineka Media.

Irawan, F. A. (2018). Pengembangan Alat Bantu Push Up (Push Up Counting) Sebagai Alternatif Perangkat Kebugaran Jasmani. Jurnal Media Ilmu Keolahragaan Indonesia, Volume 8 Nomor 1, 26-29.

James, D. A., \& Petrone, N. (2016). Sensors And Wearable Technologies In Sport: Technologies, Trends And Approaches For Implementation. Berlin, Germany: Springer, 1-11.

Kos, A., Wei, Y., Tomazic, S., \& Umek, A. (2018). The Role Of Science And Technology In Sport. Procedia Computer Science, 129, 489-495.

Kusmindari, C. D. (2016). Design Push Up Detector Using Quality Function Deployment Method And Anthropometry. The 5th Iciba 2016, International Conference On Information Technology And Engineering Application, 1-12.

Muzakir, A. (2016). Rancang Bangun Aplikasi Push Up Detector Untuk Mendeteksi Kesalahan Gerakan Push Up. Prosiding, Annual Research Seminar (Ars).2(1), 93-96.

Nilsson, M., \& Wilen, H. (2016). Push Up Tracking Smartphone Sensors. Kth Institute Of Technology School Of Computer Science And Comunication.

Park, J., Je, Y., Lee, H., \& Moon, W. (2010). Design Of An Ultrasonic Sensor For Measuring Distance And Detecting Obstacles. Journal Ultrasonics, 50(3), 340-346.

Rahmat, E. (2017). Pengembangan Teknologi Tes Chin Up Berbasis 
Arduino Uno Dan Sensor Laser Infrared Dengan Lcd Display. Jurnal Terapan Ilmu Keolahragaan,Volume 2 Nomor, 14-17.

Rosadi, D. (2018). Pengembangan Teknologi Alat Ukur Push Up Berbasis Microcontroller Dengan Sensor Ultrasonic. Jurnal Terapan Ilmu Keolahragaan, Volume 3 Nomor 1, 34-39.

Sumantri, A. (2020). KONTRIBUSI KEKUATAN OTOT LENGAN TERHADAP KETERAMPILAN SMASH BOLAVOLI DI SMAN 2 SELUMA. Kinestetik: Jurnal Ilmiah Pendidikan Jasmani, 4(1), 1-6.

Suryabrata, S. (2008). Metodologi Penelitian. Jakarta : Raja Grafindo Persada.

Syafruddin. (2011). Ilmu Kepelatihan Olahraga, Teori Dan Aplikasinya Dalam Pembinaan Olahraga. Padang : Unp Press.

Winarno, M. E. (2004). Evaluasi Dalam Pendidikan Jasmani Dan Olahraga. Jakarta : Center For Human Capacity Development. 